\title{
Reaktive artritter
}

\author{
Tore K. Kvien \\ Revmatologisk avdeling, Diakonhjemmet sykehus
}

Reaktive artritter er artrittsykdommer som forekommer i ledd som konsekvens av infeksjoner et annet sted i kroppen ${ }^{1-3}$. Typiske eksempler er chlamydiainduserte artritter og artritter indusert av patogene tarmbakterier ${ }^{4}$.

\section{HistORIKK}

Reiters syndrom er den historisk typiske form for reaktiv artritt. Hans Reiter beskrev i 1916 en kavallerioffiser som utviklet uretritt, konjunktivitt og artritt. Eponymet Reiters syndrom brukes langt mindre enn før $^{5}$ og reaktive artritter regnes som en av spondylartropatiene (som ellers omfatter Bekhterevs sykdom, psoriasisartritt og enteropatiske artritter $)^{6-8}$.

\section{KRITERIER}

Det finnes ingen etablerte diagnostiske kriterier eller klassifikasjonskriterier når det gjelder reaktive artritter. Det typiske kliniske bildet består av en artrittform som kan være oligoartikulær eller monoartikulær, men en sjelden gang også polyartikulær, ${ }^{4,-11}$. Ved revmatoid artritt er det vanligvis affeksjon av småledd i hender, men disse leddene er sjelden affisert ved reaktive artritter $^{12}$. Mer vanlig er affeksjon av knær, ankler, håndledd og tærnes grunnledd ${ }^{4,9,10}$.

\section{HVILKE INFEKSJONER ER ASSOSIERT MED REAKTIV ARTRITT?}

En rekke undersøkelser har vist at salmonella ${ }^{13-15}$, shigella $^{16}$, yersinia ${ }^{17-19}$, kampylobacter ${ }^{20-23}$ og chlamydia trachomatis ${ }^{4,24,25}$ er assosiert til reaktiv artritt, og at rundt $10 \%$ av de infiserte kan få artritter ${ }^{26}$. Streptokokkutløst revmatisk feber var vanlig tidligere, men er nesten forsvunnet $\mathrm{i}$ industrialiserte land, men reaktiv artritt etter streptokokkinfeksjoner kan forekomme ${ }^{27,28}$. Ellers er det rapportert reaktiv artritt i lav forekomst etter mange typer av infeksjoner, blant annet har norske undersøkelser foreslått assosiasjon til helicobacter $^{29}$, yersinia pseudotuberkulosis ${ }^{30}$ og chlamydia pneumoniae $^{31,32}$.
Akutt sarkoidoseartritt (Løfgrens syndrom) har et klinisk bilde som kan forveksles med reaktiv artritt, opptrer med en svingende insidens gjennom året (høyest om våren) og man har tenkt seg at en forutgående infeksjon kan være disponerende ${ }^{33}$.

\section{INSIDENS OG PREVALENS}

Norske undersøkelser har vist at insidensen av reaktiv artritt er på samme nivå som revmatoid artritt hos unge mennesker ${ }^{10}$. Hos mennesker over 50 år er revmatoid artritt langt vanligere enn reaktiv artritt. En svensk undersøkelse av ulike typer av artritter viste også insidens av reaktiv artritt på samme nivå som revmatoid $\operatorname{artritt}^{34}$, og en finsk undersøkelse peker i samme retning $^{35}$. En norsk undersøkelse viste at chlamydiaindusert artritt var omtrent like hyppig som artritter indusert av enterobakterier (yersinia, salmonella, campylobacter $)^{10}$.

Insidensen av andre artritter som er assosiert til mikrober (borrelia, streptokokker, chlamydia pneumonia) er ukjent. Prevalensen av reaktiv artritt er lav fordi de fleste pasienter går i remisjon ${ }^{9}$.

\section{Prognose}

Prognosen er god, men noen pasienter utvikler kronisk sykdom. De fleste av disse vil utvikle et Bektherevlignende syndrom og risikoen for kronisitet er i noen undersøkelser assosiert til tilstedeværelse av vevstypeantigenet HLA-B2 $7^{1}$.

\section{FORSKNINGSAGENDA}

Det er viktig å få en klarere forståelse av de mekanismer som gjør at noen pasienter utvikler kronisk sykdom. Det ser ikke ut til at langvarig antibiotikabehandling påvirker forløpet ${ }^{11}$, og mer kunnskap trengs om behandling. Man kan tenke seg at pasienter med selvbegrenset artritt uten at man påviser utløsende infeksjon har en uidentifisert triggende infeksjon ${ }^{4}$. Selvbegrenset artritt kan altså dreie seg om en form for reaktiv artritt med uidentifisert triggende mikrobe.

\section{REFERANSER}

1. Leirisalo-Repo M. Reactive arthritis. Scand J Rheumatol 2005; 34 (4): 251-259.

2. Toivanen A, Toivanen P. Reactive arthritis. Curr Opin Rheumatol 1996; 8 (4): 334-340.

3. Keat A. Reiter's syndrome and reactive arthritis in perspective. $N$ Engl J Med 1983; 309 (26): 1606-1615.

4. Kvien TK, Glennas A, Melby K et al. Reactive arthritis: incidence, triggering agents and clinical presentation. J Rheumatol 1994; 21 (1): 115-122.

5. Lu DW, Katz KA. Declining use of the eponym "Reiter's syndrome" in the medical literature, 1998-2003. $J$ Am Acad Dermatol 2005; 53 (4): 720-723. 
6. Khan MA. Spondyloarthropathies. Curr Opin Rheumatol 1994; 6 (4): 351-353.

7. Olivieri I, van Tubergen A, Salvarani C, van der Linden S. Seronegative spondyloarthritides. Best Pract Res Clin Rheumatol 2002; 16 (5): 723-739.

8. Dougados M, Hochberg MC. Why is the concept of spondyloarthropathies important? Best Pract Res Clin Rheumatol 2002; 16 (4): 495-505.

9. Glennas A, Kvien TK, Melby K et al. Reactive arthritis: a favorable 2 year course and outcome, independent of triggering agent and HLA-B27. J Rheumatol 1994; 21 (12): 2274-2280.

10. Kvien TK, Glennas A, Melby K et al. Reactive arthritis: incidence, triggering agents and clinical presentation. J Rheumatol 1994; 21 (1): 115-122.

11. Kvien TK, Gaston JS, Bardin T et al. Three month treatment of reactive arthritis with azithromycin: a EULAR double blind, placebo controlled study. Ann Rheum Dis 2004; 63 (9): 1113-1119.

12. Kvien TK, Glennas A, Melby K. Prediction of diagnosis in acute and subacute oligoarthritis of unknown origin. Br J Rheumatol 1996; 35 (4): 359-363.

13. Locht H, Molbak K, Krogfelt KA. High frequency of reactive joint symptoms after an outbreak of Salmonella enteritidis. $J$ Rheumatol 2002; 29 (4): 767-771.

14. Locht H, Kihlstrom E, Lindstrom FD. Reactive arthritis after Salmonella among medical doctors - study of an outbreak. J Rheumatol 1993; 20 (5): 845-848.

15. Mattila L, Leirisalo-Repo M, Koskimies S, Granfors K, Siitonen A. Reactive arthritis following an outbreak of Salmonella infection in Finland. Br J Rheumatol 1994; 33 (12): 1136-1141.

16. Gaston JS. Shigella induced reactive arthritis. Ann Rheum Dis 2005; 64 (4): 517-518.

17. Hannu T, Mattila L, Nuorti JP et al. Reactive arthritis after an outbreak of Yersinia pseudotuberculosis serotype O: 3 infection. Ann Rheum Dis 2003; 62 (9): 866-869.

18. Simonet ML. Enterobacteria in reactive arthritis: Yersinia, Shigella, and Salmonella. Rev Rhum Engl Ed 1999; 66 (1 Suppl): 14S-18S.

19. Gran JT, Paulsen AQ, Gaskjenn H, Schulz T. Reactive arthritis of the cervical spine due to Yersinia enterocolitica in a patient with preexisting ankylosing spondylitis. Scand J Rheumatol 1992; 21 (2): 95-96.

20. Hannu T, Kauppi M, Tuomala M, Laaksonen I, Klemets P, Kuusi M. Reactive arthritis following an outbreak of Campylobacter jejuni infection. J Rheumatol 2004; 31 (3): 528-530.

21. Hannu T, Mattila L, Rautelin H et al. Campylobacter-triggered reactive arthritis: a population-based study. Rheumatology 2002; 41 (3): 312-318.

22. Melby KK, Svendby JG, Eggebo T et al. Outbreak of Campylobacter infection in a subartic community. Eur $J$ Clin Microbiol Infect Dis 2000; 19 (7): 542-544.

23. Pope JE, Krizova A, Garg AX, Thiessen-Philbrook H, Ouimet JM. Campylobacter reactive arthritis: a systematic review. Semin Arthritis Rheum 2007; 37 (1): 48-55.

24. Bas S, Griffais R, Kvien TK, Glennas A, Melby K, Vischer TL. Amplification of plasmid and chromosome Chlamydia DNA in synovial fluid of patients with reactive arthritis and undifferentiated seronegative oligoarthropathies. Arthritis Rheum 1995; 38 (7): 1005-1013.

25. Bas S, Cunningham T, Kvien TK, Glennas A, Melby K, Vischer TL. Synovial fluid and serum antibodies against Chlamydia in different forms of arthritis: intra-articular IgA production in Chlamydia sexually acquired reactive arthritis. Br J Rheumatol 1996; 35 (6): 548-552.

26. Leirisalo-Repo M, Hannu T, Mattila L. Microbial factors in spondyloarthropathies: insights from population studies. Curr Opin Rheumatol 2003; 15 (4): 408-412.

27. Gibofsky A, Zabriskie JB. Rheumatic fever and poststreptococcal reactive arthritis. Curr Opin Rheumatol 1995; 7 (4): 299-305.

28. Mackie SL, Keat A. Poststreptococcal reactive arthritis: what is it and how do we know? Rheumatology 2004; 43 (8): 949-954.

29. Melby KK, Kvien TK, Glennas A. Helicobacter pylori - a trigger of reactive arthritis? Infection 1999; 27 (45): 252-255.

30. Gran JT, Forseth KO, Lassen J. [Reactive arthritis following Yersinia pseudotuberculosis infection]. Tidsskr Nor Lageforen 1990; 110 (4): 485-487.

31. Melby KK, Kvien TK, Glennas A, Anestad G. Chlamydia pneumoniae as a trigger of reactive arthritis. Scand J Infect Dis 1999; 31 (3): 327-328.

32. Gran JT, Hjetland R, Andreassen AH. Pneumonia, myocarditis and reactive arthritis due to Chlamydia pneumoniae. Scand J Rheumatol 1993; 22 (1): 43-44.

33. Glennas A, Kvien TK, Melby K et al. Acute sarcoid arthritis: occurrence, seasonal onset, clinical features and outcome. Br J Rheumatol 1995; 34 (1): 45-50.

34. Soderlin MK, Borjesson O, Kautiainen H, Skogh T, Leirisalo-Repo M. Annual incidence of inflammatory joint diseases in a population based study in southern Sweden. Ann Rheum Dis 2002; 61 (10): 911-915.

35. Savolainen E, Kaipiainen-Seppanen O, Kroger L, Luosujarvi R. Total incidence and distribution of inflammatory joint diseases in a defined population: results from the Kuopio 2000 arthritis survey. J Rheumatol 2003; 30 (11): 2460-2468. 